\title{
From globality to partiality: Semiotic practices of resistance to the discourse of war
}

\author{
Daniele Monticelli \\ Dept. of German and Romance Language and Literature, \\ University of Tartu \\ Ülikooli 17, 50090 Tartu, Estonia \\ e-mail: monticelli@hot.ee
}

\begin{abstract}
This paper examines the discourse of war from a semiotic point of view and suggests some ideas for the development of practices of resistance to it. The discourse of war can be considered symptomatic in respect to underlying discourses of totality such as globalisation. By aiming at explanatory simplification, this kind of discourse takes the paradoxical form of an exhaustive paradigm which always engenders a residuum to be eliminated. Semiotics can develop practices of resistance to the discourse of war by operating on the syntagmatic chains generated by its mediatic agencies. These practices are based on the postmodernist critique of totalising discourses. A process in which details are disconnected from the mediatic chains where they vanish might trigger the opening of a space of community that makes the residuum of war discourse presentable through metaphorical substitutions. Semiotic practices of resistance to the discourse of war presuppose a shift in theory from the paradigm of globality to that of partiality. Partiality must be understood both from a political and an epistemological point of view and it could therefore represent an important element in the development of a semioethics.
\end{abstract}

Some striking similarities are, in my opinion, evident in the debate of recent years about the situation in the humanities and social sciences in general (and semiotics in particular) on the one hand and the discussion about globalisation on the other. These similarities are evidently due to the critical problematisation of the "modernist project" (Pettman 2004: 13), within which the kind of rationality constituting the ideological basis of Western knowledge has been responsible for the kind of World Order represented by globalisation and finds in it its own accomplishment. 
In the case of the social sciences and humanities the main focus of the discussion has been on the contraposition between an ideal of unity and one of multiplicity (hence the various distinctions between 'science' and 'studies', 'unified method' and 'plurality of approaches' or 'theory' and 'practices'). The almost universal claim about the vanishing boundaries between individual disciplines and the interdisciplinarity of the humanities hides the attempts of different methods of research to gain a hegemonic position, something particularly evident in the recurring inclination of semioticians to present themselves as the new methodologists of the humanities and social sciences. In the discussion about globalisation, the terms of the problem seem to be quite similar. Much in focus is the distinction between the principles of universalisation/assimilation on the one hand, and those of differentiation on the other. The question of hegemony also has a strategic role here, and it has been sometimes asked to what extent alternative forms of existence will be able to continue in the age of the pensée unique or "global monoculture" (Anderson 2004: 2). War is the extreme moment, when the polemical aspects deeply inscribed in the logic of globalisation become overriding.

In this paper I will consider what can be called the 'discourse of war' and show its symptomatic status in relation to the underlying discourses of totality (such as globalisation). I will then try to put forward some proposals for the development of semiotic practices grounded on partiality, which could be opposed to the discourse of war. In doing so, I will take sides in the debate mentioned above, arguing that a semiotic theory should be thought of as a set of practices which can function as a generator of resistance to totalising discourses. This is what a 'semioethics' should look like, rather than like a 'science' with a unified method.

\section{Globalisation and semiotics}

At the end of the $1980 \mathrm{~s}$, when the totalitarian regimes of Eastern Europe started to collapse, the feeling that a new era of peace and freedom was about to begin was widespread. The fears of annihilation which were experienced during the Cold War disappeared. These fears had had a material basis insofar as they were related to different 
degrees of embodiment: the physical division of the body of humanity into two (East and West separated by the Iron Curtain); the deportation and imprisonment of individuals as an instrument of the dismemberment of national and social bodies (particularly in the Soviet Union), and the dissolution of individual bodies (as a consequence of a possible nuclear war).

The end of the Cold War coincided with an impressive acceleration of so-called globalisation, which in Western societies took the form of 'informatization', a progressive dematerialisation or disembodiment of everyday-life with an increasing amount of human interaction taking place through exchanges of information within a virtual environment. ${ }^{1}$ The protagonist of this process is the new media: what represents globalisation better than the World Wide Web? These changes appeared very promising for semiotics. In fact, the dematerialisation of reality can also be seen as a progressive semiotisation of our world. Globalisation and its new media have enormously enlarged the portion of reality which is graspable by the methods of semiotics. The web, with its nodes and inter-related threads, is exactly the kind of structure semioticians have been accustomed to dealing with from the very beginning of their discipline (a classical Saussurean structure and a web can be seen as isomorphic construction). In these conditions the dream of a global semiotics, which would be the most natural theoretical way to describe our new world in exactly the terms of a "semiotic web", seemed to be justified. Global semiotics can be seen from this point of view as an attempt to extend a method originally thought of and developed to deal with human (social/cultural) artefacts as systems of signs, to cover all the phenomena of the biological world: "the activity of signs, or 'semiosis', extends in principle to the whole of being as 'knowable"" (Deely 2005: 7; see also Sebeok 2001: 10: "The criterial mark of all life is semiosis"). The condition of possibility for the development of a global semiotics could therefore be found in one of the (realised or

Globalisation brought in this sense to full realisation what Guy Debord defined as "the spectacle". As Debord explains, the spectacle must not be thought of as a simple set of images, but as a social relation between persons (Debord 1995: 16). I will return later to the consequences of this fact. 
dreamed of) aspects of globalisation: the culturalisation/humanisation of nature as a reduction of its alterity. ${ }^{2}$

At the foundations of the dream of globalisation thus lies an ideal of intelligibility or transparency, just as if the sources of opacity could once and for all be removed, connections substituting for divisions, previous alterity becoming penetrable and therefore knowable through already existing means. The information society naturally finds its Other in the Third World; the undeletable materiality of hunger and disease is the challenge to globalisation. But if in the past the (barbarian) Other was seen with terror, as a constant threat of chaos to the order of civilization, at the beginning of the 1990s globalisation seemed to be the power which would make that which was still something else finally 'our own'. The expansion of the Western system to the former East of the Communist Bloc had already successfully shown the power of market values; if this happened in a case in which the other side had a strong form of its own, why should it not happen in the case of the Third World, a space that we Westerners are used to imagining as having no systemic form at all? The increasing transparency granted by globalisation was thought to mean that the world would become increasingly readable for us Westerners, as our capacity to interpret reality thousands of miles away from home with the aid of our cultural codes. The dream of globalisation can be described in semiotic terms as a dream of assimilation without contamination of the original system, like the imposition of a form on an amorphous matter. Assimilation in fact presupposes a preliminary disarticulation of the pre-existent forms: the charge of symbolic violence through which the "external culture"

2 I am not saying that global semiotics agrees with these aspects of globalisation. On the contrary, it can be understood as a polemical reaction to them. It simply seems to me that the "delinguistization" and consequent "biologization" (Sebeok 2001: xxi) or "animalization" (Deely 2005) of man suggested by global semiotics presupposes in some sense a preliminary 'culturalisation' or 'humanisation' of the biological by theory. The question is that of whether Saussure was too logocentric or whether, on the contrary, he was not yet able to imagine the extraordinary power of language (systems of signs) in the society of the spectacle to substitute itself for reality, creating its own separated world and the subjects inhabiting it as essentially linguistic beings. I think that a theoretical attempt to fill the gap between culture and nature cannot ignore these points. 
destroys the "internal cultures" (Tarasti 2005) becomes here immediately evident. ${ }^{3}$

The illusions promoted by globalisation were brought to a halt by an unexpected fact: the growing centrality of war in our new world. Examples of resistance to the global order provoked a return to the violence of colonization, a return to expansion through annihilation of the Other. To think of war as a momentary difficulty in the peaceful process of globalisation is to miss the point. War is the symptom which reveals the essence of globalisation as violence and at the same time its purest, supreme means. I think that semioticians cannot ignore this fact any more, but this paper will not be an attempt to develop a new component of the global web of semiotics, a semiotics of war which could be add to the semiotics of life, culture, passions and so on. Such an attempt would result in a 'discourse about' with its own method and that is exactly what I do not want to do. Rather, the aim of this paper is to show how semiotics could go about developing a critical attitude towards war, and the kind of practices which would follow from this. The object of these practices would not be war in itself but the discourse of war and its mediatic agencies, in the spirit of what Umberto Eco has described as semiological guerrilla warfare (Eco 1986). That is, instead of taking language as a merely partial aspect of the global semiotic web of the 'semiotic animal', I will try to bring partiality into language taken as the global semiotic web itself. ${ }^{4}$

3 In the terms of globalisation we could think in a provocative way about the disarticulation and dissolution of the Soviet Union and the consequent formation of national states with weak economies as the creation of forms which are easily penetrable by international capital and other assimilating forces. The violence of the process is evident in the consequent marginalization of a significant part of the population. This means that the nation and nationalism can not always be considered as a hindrance to globalisation. The national state can be seen in this perspective as "the form whose homogenizing drive connects the apparent particularity of national identities to the greater homogeneity of universal history" (Lloyd 1997: 182).

4 I do not claim that this is the 'right way out', simply that it fits well with the kind of critical practice I am going to develop in what follows. 


\section{The paradoxical character of wartime}

I will take as a starting point three different theoretical ways to approach war, covering a stretch of time from the First World War until the first Gulf War of 1991. The somewhat contradictory ideas contained in the texts to be examined will help me to draw the reader's attention to the different components of what will be defined as the discourse of war, as well as to the changes triggered in it by the development of its agencies, the media.

In an article written in 1915, Sigmund Freud described war as a "whirlwind" [Wirbel] in which participants are confused by the significance of the impressions that overwhelm them (Freud 1974: 35). He writes of "wartime" as a complex process, a peculiar time, when violence knows no limit and overwhelms with blind rage anything that stands in its way, as though there were to be no future and no peace afterward (Freud 1974: 38). In the terms used here above, what the whirlwind of wartime destroys is the intelligibility and transparency of the world we live in. We lose the necessary 'distance' from the transformations that are taking place and remain in the dark. Freud defines this psychological condition as the end of belief in the power of human acculturation, a "disenchantment" [Enttäusschung] to which individuals react by trying to direct outward the disorienting forces menacing their stability. If wartime represents a danger to individuals because it tears them out of their "place", it simultaneously mobilises those very same disintegrating forces against an Other, which is labelled as the enemy (Weber 1997: 94).

Similarly to Freud, Emmanuel Levinas sees in war the establishment of an order from which no one can remain at a distance. War reduces individuals to bearers of impersonal powers, which direct them (Levinas 1996: 6). Levinas, therefore, links war to that kind of totality which characterizes Western thought: the goal of both is the reduction of the Other to the Same. Totality coincides with the exhaustion of all exteriority, the closure of the system, recalling the lack of future of Freud but also the ideas of such theoreticians of the global world as Francis Fukuyama about the "end of history". War serves totality in two ways: firstly by making individuals bearers of an impersonal universality, and secondly by actively leading them to neutralise the Other which would otherwise remain exterior to the totality. That is why, according to Levinas, peace always has an 
eschatological nature and the Other is linked with infinity: both bear the signs of the exteriority, the open, the not-still as opposed to totality (Levinas 1996: 8-9). ${ }^{5}$

The third text I will briefly consider is the much-discussed essay by Jean Baudrillard about the Gulf War. What Baudrillard insists upon is the dematerialization and the virtuality of war in our time. This is accomplished by the media where the events vanish in information itself, stripping war of its passions and violence and re-clothing it with "all the artifices of electronics as with a second skin" (Baudrillard 1995: 64). The disorienting effect of war (the Freudian whirlwind) does not disappear: it is now triggered by the media which, by liquidating the event in an infinite series of repetitions, speculations, interpretations, transforms the spectators into "corpses in the charnel house of new signs" (Baudrillard 1995: 76). War, therefore, functions in Baudrillard as a symptomatic device; it reveals that the dematerialising power of the media engenders a new, radical opacity in respect to the events which are deleted by discourse. This has become possible in contemporary society, where the spectacle, alienating language, constitutes it as the separated world in which we live (Agamben 2000: 81). The media does not bring war nearer to us, into our houses, as some say. We do not really know more about war than Freud's contemporaries did. Anyway, it would be false to think that the mediatic unreality of war implies its lack of real effects. The mobilizing power of war, as stated by Freud and Levinas, remains unquestionably in place in the age of the spectacle too. Media sources has simply become the new "storm troopers" (Agamben 2000: 94) of the discourse of war and, at the same time, the media has become the battlefield where it is really decided who shall win (Vietnam was an earlier example of this shift. In the case of Iraq it would be very difficult to decide who won the war, if the media had not told us that the US did.)

5 In his comment on Levinas' book, Derrida diverges from the author of Totality and Infinity in that he situates the Other within language and history, where it can never be thought of as a 'positive infinity', but always as maintaining within itself the negativity of the indefinite. This is a very important point for my argument, because Derrida links in-finity and partiality to finitude and positions them all straight into language: "The other cannot be what it is, infinitely other, except in finitude and mortality (mine and its). It is such as soon as it comes into language" (Derrida 2004: 143). I will return to this later. 
The synthetic exposition of Freud's, Levinas' and Baudrillard's ideas about war has brought to light a kind of paradox in the logic of wartime, whose consequences will be of great importance in what follows. 'Wartime' brings with it an overwhelming lack of transparency and intelligibility in people's relationship with the events which are taking place. The impossibility of remaining at a distance is established by the tyranny of a present which ends future and past in the 'real time' of the media. ${ }^{6}$ But, simultaneously, wartime triggers also a shortcut to that sort of simplifying intelligibility which is characteristic of all discourses of totality. The tyrannical present of wartime transforms itself into presence ${ }^{7}$, the imposition of a given discourse as a closed and self-evident totality, the only possible way to look at the events. Freud describes the effects of this imposition on the "best minds" as a "logical blindness" [Verblendung] which is a secondary phenomenon following an "emotional excitation" [Gefühlserregung] (Freud 1974: 47). It is through this blindness that the mobilising potentiality of war becomes a reality.

It is precisely in this paradox (lack of intelligibility together with a shortcut to simplifying universalisations) that the symptomaticity of war in relation to globalisation begins to appear. Seeing things by means of this paradox, beyond the ideal of globalisation as a growing cosmopolitan knowledge, the asymmetrical ignorance "that stands as an indictment of the crippling and disastrous inequalities of the world system" (Hitchcock 2000: 4) will emerge. ${ }^{8}$ Let us consider, to briefly exemplify this, the phenomena which we usually call 'natural disasters' when they take place in the globalised world — this might

6 "War implodes in real time, history implodes in real time, all communication and all signification implode in real time" (Baudrillard 1995: 49).

7 See Derrida (2004: 1-35).

8 It is from this perspective that Tarasti proposes precisely the coming to an end of both the future and the past which was discussed above, as fundamental to globalization. For individuals, this means uncertainty and an impossibility either to make long term plans or to resort to history in the search for explanatory criteria (Tarasti 2005). William E. Connolly develops the same ideas at the level of the State: "global contingencies" are, in his view, "possibilities and potential emergencies that might be resistant to control". Global contingencies engender a gap between the power of the most powerful states and the power they would require for self-government and self-determination. The drive to close this gap causes, in Connolly's view, a rise of disciplinary pressure in the domestic sphere and represents a serious danger to global survival (Connolly 2002: 24-25). 
also give a further explanation of the doubts expressed above about global semiotics. In both the cases of the South-east Asian Tsunami and Hurricane Katrina in New Orleans what strikes our imagination as something unthinkable (a paradox) is the coexistence of a perfectly transparent knowledge (sanctioned by science) of the event with the absolute opacity of what is taking place. It is enough to look at the victims of the two disasters to see how the paradox finds its explanations in the 'asymmetrical ignorance' and the 'disastrous inequalities' characteristic of the global world mentioned above. The recurrent use of bellicose metaphors in the description of natural disasters also manifests the symptomatic quality of wartime in our representation of such phenomena.

\section{The discourse of war}

I am now ready to proceed with a semiotic analysis of the discourse of war as it manifests itself in our times. In so doing, I will sum up the elements presented so far, and add some new perspectives. In essence, it is possible to explain the paradox referred to earlier by postulating a functional detachment between the paradigmatic and the syntagmatic levels of the discourse of war. It is here that a space opens for semiotic practices of resistance to this discourse.

At the paradigmatic level it is particularly evident that the discourse of war is based on what Levinas called totality, the thing that we often hear of and recognize today as 'fundamentalism'. In fact, the paradigmatic oppositions of the war discourse are all grounded in a fundamental and irreducible difference, that between we and they strengthened by the principle 'anyone who is not with us is against us', making the paradigm an exhaustive classification in which everything is comprehended without any exteriority. ${ }^{9}$ But the disposition of the two terms of this opposition on the same level is only apparent. Actually we encounter here what Sidra Dekoven Ezrahi has called an apocalyptic logic based on chosenness. In this kind of totalising discourse, Ezrahi writes, "we don't see in them a reflection of our

9 The inscription of the tertium non datur principle in the discourse of war was, for instance, a very important point in George W. Bush's speeches after the September 11 attacks. 
humanity" because "there is really no room in the mirror for more than one reflection" (Ezrahi 2002: 66; my emphasis - D. M.). This removal of humanity is a process in which the identity of the enemy is disarticulated, and the enemy is excluded from all possible (social, juridico-political, cultural) attributions. Paradoxically, the exhaustive classification mentioned above therefore generates, by its very functioning, a residuum. This kind of residuum is very similar to the one generated by what in political and legal theory is known as a "state of emergency" and Giorgio Agamben re-defined in a broader philosophical perspective as a "state of exception" (Agamben: 2005). A state of exception is a state of suspension of the law, in which the individuals who are subjected to it suffer a deprivation of their juridico-political status and are essentially reduced to what Giorgio Agamben calls "bare life". In the state of exception power applies without mediation directly to bare life as a sovereign right over life and death (Agamben 1998: 81-86; 2000: 40). As Freud demonstrates, war is the symptomatic moment, when the citizen realizes what should have already been clear in peace time: that the State monopolises the use of violence and every possible injustice (Freud 1974: 39). It is thus possible to describe the process which is made clear by the paradigm of war discourse in terms of the process of "dislocating localization" (Agamben 2000: 43) at work in the state of exception; through it the localisation of 'us' as an exhaustive totality (for instance 'humanity') is based on the differentiation of a 'they' and its dislocation as a residuum (bare life). Karl Schmitt describes this procedure as follows:

Humanity as such as a whole has no enemies. Everyone belongs to humanity [...]. 'Humanity' thus becomes an asymmetrical counter-concept. If he [the person who speaks in the name of humanity] discriminates within humanity and thereby denies the quality of being human to a disturber or destroyer, then the negatively valued person becomes an unperson, and his life is no longer of the highest value: it becomes worthless and must be destroyed. Concepts such as 'human being' thus contain the possibility of the deepest inequality and become thereby 'asymmetrical'. (Schmitt 1987: 88) ${ }^{10}$

We therefore face a paradigm which generates diversity only to disarticulate or dislocate it, by excluding it from any possible defini-

\footnotetext{
${ }^{10}$ For a discussion about the construction of humanity/inhumanity in relation to war and terrorism see Butler 2004: 89-91.
} 
tional status; the above-mentioned paradox disappears when we think at the constitution of the enemy into a residuum as the legitimising precondition for its annihilation which restores the self-sufficiency of the totality. Note that the inequality and asymmetricality mentioned by Schmitt in this case are actually of the same kind as those described above as characteristic of globalisation.

There are some terms which bring this kind of totalising activity to an extremity, and they seem to function within the paradigm of war discourse in an unrelational way, as if they had an extra-systemic value. In the Western discourse of war, such terms include for instance 'freedom' and 'democracy'. When asked, George W. Bush frequently gives quite a deceptive definition of them, for example by saying that Americans had the opportunity to vote him out of office, but they did not use it (and that this is democracy) or that the State must serve citizens, not vice-versa (and that this is freedom). ${ }^{11}$ But 'freedom' and 'democracy' acquire a somewhat magical value in the discourse of war, where they figure as universals not subject to (syntagmatic) definition or (paradigmatic) relativisation: they own "the redemptive unity of the Idea" in respect of the abjection of war (Kristeva 1982: 145). This unity takes precisely the form of the 'dislocating localization' encountered before: 'We all want freedom and democracy, but they don't.'

It is possible to summarize the different aspects of the paradigm of the discourse of war using Levinas's observations about the two ways in which Western thought faces the relation between the Same and the Other: supremacy of the Same (apocalyptical oppositions) or reduction of the relation to an impersonal universal order (unity of the idea), where being together means being side by side all looking at the idea rather then at each other. The new concept of residuum defined here will become important in what follows.

On the syntagmatic level of war discourse we encounter the mediatic chains described by Baudrillard. Here the totalising process manifests itself as an absolute predominance of the whole over its constituent parts. It has been noted in relation to poetry that an abuse of syntagmatic procedures like alliteration can provoke strong interferences in the processing of meaning with a consequent loss of sense (Silverman 1983: 106). In the same way, repetition is the process

11 See for instance the interview released by Bush to the Estonian newspaper Postimees (Postimees, 07.05.2005). 
which establishes that, in media coverage of war, the real and singular event is always and already left behind. The relation between the syntagmatic and the paradigmatic moment of war discourse appears clearly in the words Baudrillard uses to describe what Debord and Agamben call the "society of the spectacle":

the age of simulation thus begins with a liquidation of all referentials worse: by their artificial resurrection in systems of signs, which are a more ductile material than meaning, in that they lend themselves to all systems of equivalence, all binary oppositions and all combinatory algebra. (Baudrillard 1988: 167)

If the event vanishes within the repetitive syntagmatics of war discourse, the paradigmatic order offers a shortcut to the kind of explanatory transparency described above for the case of globalisation. In a sense the paradigm does not provide us with the competence needed for the interpretation of the mediatic syntagms. Instead, it exonerates us from the need to interpret them, because their compositional logic (relations of meaning between the parts and the whole) remains opaque from the very beginning. That is why I speak of a detachment between the syntagmatic and the paradigmatic levels of the discourse of war. It is possible to think about this detachment as a double erasure, with the generation of a residuum, as shown in Fig. 1.

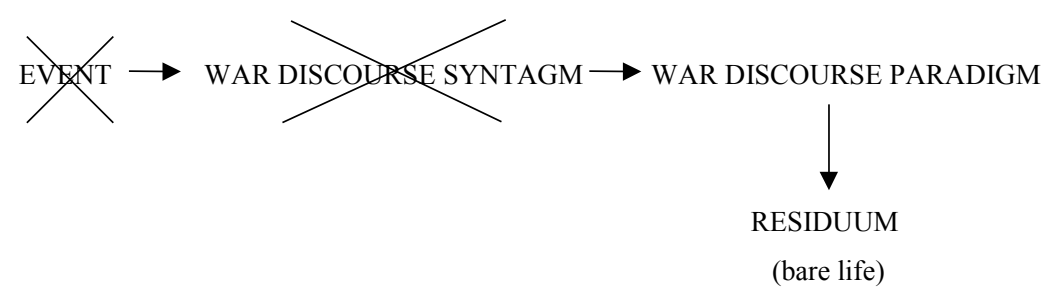

Figure 1. Double erasure and residuum.

The residuum produced by the shortcut as a consequence of the use of asymmetrically universalising concepts is precisely the point at which the discourse of war becomes symptomatic to all the discourses of totality, such as globalization. Practices of resistance to the discourse 
of war can be developed starting from its realized, that is syntagmatic, form; if the paradigm is a totalising system of classification, the syntagm always presupposes speech (Silverman 1983: 104) and, as Saussure long ago observed, it is only through speech that we can trigger changes in language.

\section{The whole and the parts}

The mediatic environment represents, in the society of the spectacle, our always-already given and it will therefore be the starting point for the semiotic practices of resistance described in what follows. First of all, the image of the media as a web must be substituted with an image better fitted to the observations made so far. It is the Italian writer Italo Calvino who offers a suitable image when, in his novel PriscillaDeath, he compares our mediatic environment or, as he writes, "everything that is language in the broad sense", to a cover (calotta is the Italian world, meaning a hemi-spherical and hard kind of cover rendered as cap by the English translator):

As soon as we are out of the primordial matter, we are bound in a connective tissue that fills the hiatus between our discontinuities, between our deaths and births, a collection of signs, articulated sounds, ideograms, morphemes, numbers, punched cards, magnetic tapes, tattoos, a system of communication that includes social relations, kinship, institutions, merchandise, advertising posters, napalm bombs, namely everything that is language, in the broad sense. [...] Like a duplicate of the Earth's crust, the cap [calotta] is hardening over our heads. (Calvino 1969: 91) ${ }^{12}$

12 Note that, in his attempt to show the extension of the category of sign, Sebeok quotes a passage from Peirce, suggesting examples that are reasonably analogous (given the difference in time) to Calvino's: "Signs in general [are] a class which includes pictures, symptoms, words, sentences, books, libraries, signals, orders of command, microscopes, legislative representatives, musical concerts, [and] performances of these, in short, whatever is adapted to making mental impressions virtually emanating from something external to itself" (Peirce, MS 634, 16-17 [September 1909], quoted in Sebeok 2001: 8-9). A relevant difference seems to lie in the fact that Calvino speaks of a covering, and therefore of a duplication, while in Peirce's terms the universe is "perfused" with signs, which are therefore represented as much more "inherent" to it (hence global semiotics). That is why, in my opinion, Calvino's image (quite similarly to Debord 1995: 21) works better than Peirce's in describing the society of the spectacle. 
The filling of empty spaces (hiatuses) caused by the cover does not mean, in Calvino's terms, the elimination of all barriers to communication, on the contrary it makes communication nonsensical and impossible, becoming an "hostile envelope", a "prison"; what we thought of as a "network" of connections (the media) turns out to be an instrument of isolation (Weber 1997: 100-101). The symptomatic nature of war in relation to the nature of the media, which we can restate in everyday terms as the 'complete coverage' of war by the media, could become a site on which semiotic practices might seek for a spot to "break the cap" trying "to prevent its perpetual selfrepetition", as Calvino puts it (Calvino 1969: 92). It seems to me that this cannot be done along the critical lines proposed by Baudrillard, because the situation has changed since 1991. If at that time the problem of the reduction and absorption of the singular into the universality of the New World Order seemed to be soluble for the West with the cleanliness of a spectacular operation (Baudrillard 1995: 86), we are now witnessing, with terrorism, the return of the fears of annihilation characteristic of the Cold War: the body of humankind divided into two (Islam and the West), the individual body exposed to dismemberment (for example in the beheadings of hostages or the falling bodies of the Twin Towers) and the social body constantly threatened by a possibly mortal virus (immigrants as potential terrorists).The discourse of war uses the vulnerability arising from these fears of constant menaces to our life to promote war as the symbolic space where we can continue to imagine ourselves as invulnerable; it does so through the process of dislocating localization described above, a mechanism which more and more transforms the state of exception into the rule of our societies: we can be 'sure' only if everyone, potentially, might be deprived of his or her juridicopolitical status and reduced to a residuum, bare life without any rights subjected to a power able to decide on his or her life and death: "power no longer has today any form of legitimization other than emergency [...] power everywhere and continuously refers and appeals to emergency as well as laboring secretly to produce it" (Agamben 2000: 6; see also Agamben 1998: 114-115, Connolly 2002: 24; Butler 2004: 50-100). ${ }^{13}$

13 Thus, in Agamben's view, the Third World, enemies of war, and the 'enemy combatants' at the prison in Guantanamo Bay are instances of bare life on the global level just as much as migrants, aliens without citizenship and the 
In search of practices of resistance to the discourse of war, it is useful to revert to the strategies of reaction to totality elaborated within the frame of postmodernist thought. ${ }^{14}$ Difference, dissemination, heterogeneity, molecularity, discontinuity (Jameson 1983: 53, 58), multiplicity and plurality (Haber 1994: 7, 18), segmentation (Silverman 1984: 246-250) are some of the concepts that postmodernist thinkers have used as critical instruments against totalising forms of discourse. What postmodernist critique tries to do is to identify those places in discourse where subjects and worlds seem to "resist recuperation within the oneness of the world" (Hitchcock 2000: 16). I want to introduce here this strategy of resistance to totality in a quite unusual way: by returning, that is, to some of Calvino's ideas about literature instead of quoting some well-known postmodernist theoretician.

In his Six memos for the next Millennium, Calvino writes about Lucrezio's De rerum natura as the first "work of poetry in which knowledge of the world tends to dissolve the solidity of the world, leading to a perception of all that is infinitely minute, light and mobile" (Calvino 1996: 8). This is why, first of all, Lucretian atomism gives rise to a "poetry of the invisible", a poetry "of infinite unexpected possibilities". Secondly, the Lucretian pulverization of reality is a means of avoiding the oppression of matter, dissolving the solidity of the world, and establishing "an essential parity between everything

inhabitants of the outskirts of great post-industrial cities (think of the Parisian banlieue!) are within the national state. Anderson uses the concept of 'fifth world' to describe "displaced persons and peoples" such as refugees or the homeless (Anderson 2004: 300-302). In terms quite similar to Agamben, Connolly describes what he calls the external Other (foreign enemies and terrorists) and the internal other (low-level criminals, drug users, the disloyals, racial minorities, and the underclass) as both functional to the "theatricality of power" which construct them as "a dispensable subject of political representation and an indispensable object of political disposability" (Connolly 2002: 208).

14 I think therefore that semiotics can and should usefully employ some of the ideas generated by the postmodernist tradition instead of proclaiming itself "the postmodern revolution in philosophy" (Deely 2005: 10; my emphasis - D. M.) or opposing its own solid "pre-socratic" origins to the "ephemeral Parisian fads" of twentieth-century thought (Sebeok 2001: 6). The 'postmodernist turn' in semiotics means giving up the idea of semiotics as a unified and unifying method and instead doing semiotics in a situation where it already appears to be: a set of different theoretical practices which employ some common concepts, defining them in very different ways. 
that exists, as opposed to any sort of hierarchy of powers or values" (Calvino 1996: 9). What is important in the Lucretian method is the recovered independence of the parts in respect to the whole to which they belonged. If Lucretrius was dealing with matter, we could apply the same process to the mediatic environment, particularly now, when Calvino's words have been used to define it as a cover, something as hard and oppressive as matter was for Lucretius.

The semiotic procedure which I would like to propose would apply the Lucretian method to the mediatic environment, disentangling small details from the uninterrupted flow of information which makes them invisible, assigning them a place only within the chains of interpretations, speculations, and argumentations. This disentanglement implies a reversal of the direction of semiotic practices: if semiotics traditionally tends to establish connections, we should instead try to favour the emergence of disconnections. ${ }^{15}$ Highlighting the detail, paying attention to it, we make room for its emergence and help it resist: "it is we alone who determine whether the world will appear and so be, or languish in the darkness of non-being" (Silverman 2000: 7). If at the beginning of the history of cinematography Walter Benjamin called the new technique shocking, because of the temporal impossibility of the spectator arresting a single scene and developing an independent train of thought about it (Benjamin 1973: 231-232), in our time, on the contrary, it is exactly the idea of stopping the continuous flow of images and words that has become shocking. Think of the fundamental role which photos, not videos, have played in the development of a critical conscience against war from Vietnam to Iraq.

The semiotic procedure here proposed relates, in my opinion, to Benveniste's ideas about the difference between the semantic and the semiotic, the first being based on understanding, the second on

15 We find a similar procedure in Barthes, where segmentation ("cutting up", "breaking", "interruption") is used to disrupt the syntagmatic order of the text and to challenge the ideological systematization imposed by a given code (Barthes 2000: 13-16). Agamben uses the term 'interruption' to characterize the process through which "the factum of language comes to light for an instant" (Agamben 2000: 70). Furthermore, Levinas speaks of the need to "break" the discourse, which vanishes otherwise into the All (Levinas 2002). Lacan seems to synthesize Calvino's intentions in the best way, when he writes: "this cut in the signifying chain alone verifies the structure of the subject as discontinuity in the real" (Lacan 2001: 331; my emphasis - D. M.). 
recognition. The only difference is that if Benveniste claims that "la seule question qu'un signe suscite pour être reconnu est celle de son existence" (Benveniste 1974: 64), in what I am trying to do this statement could be inverted as follows: "the detail is called into existence as a sign only if it is recognized". Recognition has, therefore, the form of a shock, a short circuit in the system which disentangles the detail from the syntagmatic chain, where it figured as an insignificant part. The question is now "which kind of recognition?", because, as shown above, the discourse of war has its own paradigm and inside this paradigm recognition is achieved on the basis of the all-important opposition between we and they. The kind of recognition I am thinking about should be able to disrupt exactly this paradigm. As a basis for this idea of recognition, Kaja Silverman's description of different kinds of resemblance (Silverman 1983: 87-125) might be useful. Drawing on Freudian and Lacanian psychoanalysis, Silverman argues that we can distinguish between three kinds of resemblance, those related respectively to paradigm, condensation and metaphor. Differences and distinctions are fundamental to the paradigm which is organized on a relational logic and based on binary oppositions, where "the parts have value by virtue of their place in the whole" (Saussure 1966: 128, quoted in Silverman 1983: 105). The paradigm is the place of the we/they and all the other related oppositions of the discourse of war, as shown above. Condensation refers to what Freud calls 'primary processes' (like dreams) and collapses distinctions between different elements to achieve absolute identification. In condensation, "each manifest signifier refers to a group of latent signifieds", highly economically; "under its [condensation] influence the part stands for the whole, a single figure represents a diverse group" (Silverman 1983: 91). The mechanism of condensation appears to be at work in the above mentioned "redemptive unity of the Idea" with its charge of symbolic violence. Is it not as if in some kind of dreamlike conditioning that 'freedom' and 'democracy' impose themselves as self-evident universals? Metaphor lies in between: it is neither complete identity, nor irreducible difference, "it permits profound affinities and adjacencies to be discovered without differences being lost" (Silverman 1983: 109). If paradigm and condensation are grounded on presence and exhaustive closure (all is here now and there is nothing more), in metaphor it is the 'principle of absence' that becomes central. It is precisely because of the uneliminable partiality of the metaphor (a metaphor is a substitution legitimated 
only in some respect) that the hidden term is never exhausted in the substitution, never totally present. That is why it would be more precise to consider the ground of a metaphor not as a sign, but as a trace, where something is "present not as a total presence" (Derrida 2004: 119, 135; see also Derrida 1997: 44-73). The disentangled detail can become the ground for this kind of metaphorical recognition linking the Self and the Other, where the Other is absent but evoked by the detail functioning as its trace. As in Lacan and Levinas, absence triggers desire and desire puts into motion a series of further recognitions.

\section{Opening the space of community: partiality, in-finity and finitude}

It is now possible to change Figure 1, as shown in Figure 2.

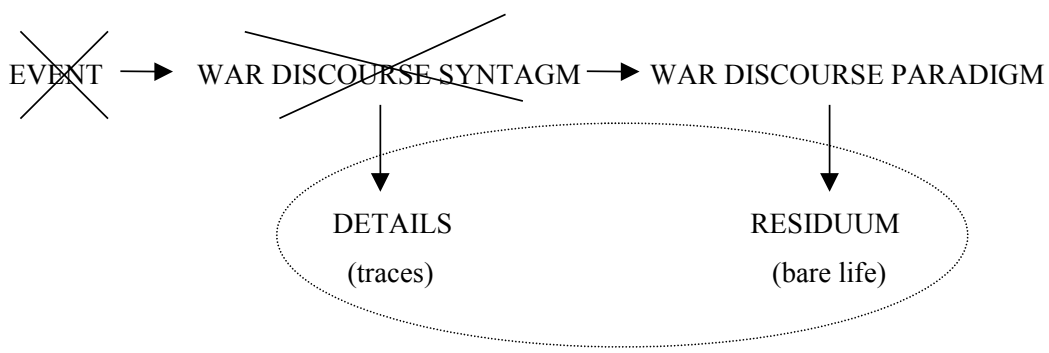

Figure 2. Disentanglement of the detail and space of community.

\footnotetext{
16 Basing the kind of disconnections I am discussing here on recognition and resemblance, I take the risk of once more emphasising similarity at the expense of difference. Anyway, as Honi F. Haber has shown, the universalisation of difference, like the universalisation of totality, prevents the elaboration of every possible strategy of resistance. The latter become possible only insofar as "sometimes we recognize parts of ourselves in the stories of others" (Haber 1994: 43; see also Whitebrook 2001: 150-151 and Connolly 2002: ix-xxxi). Anyway, unlike the last two authors, I will not use the concept of 'identity' to describe the kind of resemblance I am speaking about, for reasons that will be explained below.
} 
The disconnection of the detail from the mediatic chain opens a space of 'community', where the Other generated and dislocated by the paradigm of war discourse as a residuum (bare life) can be experienced by us. Opening up this space means resisting the alienation of language as our power to communicate in the world of the media, the cover which fills all the empty spaces between our discontinuities only to make communication impossible and the place where "human beings are kept separate by what unites them" (Agamben 2000: 84). To open up the space of community therefore means bringing "language itself to language" (Agamben 1993: 82). The space of community is the space of the re-instituted power of language, the space of total possibility that Derrida, following Heidegger, identifies with Being, not as a given predicate but as "what authorizes all predicates" and "far from closing difference, on the contrary liberates it" (Derrida 2004: 175, 406). In comparison with the fullness of being (universality) represented by the paradigm of war and the non-being of the residuum as bare life (exception), we can define the space of community opened by the disconnection of the detail as the space of the possibility to not not-be (Agamben 1993: 31). The kind of community here imagined has nothing to do with identity (which grounded the paradigmatic opposition between we and they); on the contrary, the space of community should be thought as a space of pure communicability, pure mediality, where instead of identity a principle of unconditioned substitutability (Agamben 1993: 24-25) is in force. If the rhetoric of identity was the premise for the universal representability and the self-identification of individuals inside the paradigm of the discourse of war, anti-identitarian substitutability will be the way to present within the space of community what that paradigm dislocated as something unpresentable (residuum, bare life) to be destroyed. In his theory of the text, Barthes defined this kind of unconditioned substitutability as an "unbridled (pandemic) circulation of signs", which "abolishes the power of legal substitution" exhaustively regulated by the paradigmatic oppositions (Barthes 2000: 215216).

It is interesting to note the way that the opening of the space of community triggered by the disentangled detail becomes paradoxically possible, in spite of Baudrillard's pessimism, exactly because of the separation of language in an autonomous sphere accomplished by the media in the society of the spectacle. This is the positive aspect 
of what Benjamin earlier defined as the "loss of aura" of the work of art due to its mechanical reproducibility (Benjamin 1968: 215). The society of the spectacle, more generally, can be defined as the "devastating experimentum linguae that disarticulates and empties, all over the planet, traditions and beliefs, ideologies and religions, identities and communities" (Agamben 2000: 85); this experiment makes it possible for us to fully experience our linguistic being. Derrida stresses how Levinas too never condemned technology, on the contrary he saw in it the possibility of letting the human face shine in its nudity as opposed to the violence of the traditional "taking root", or "implantation in the Site" (Derrida 2004: 400, 409). Thus the simplifying transparency of the paradigm of war discourse and the relative practices of identification obtained through double erasure and shortcut (fig. 1) need not be the only possible results of the constitution of language as an autonomous sphere within the society of the spectacle. The latter contains a positive possibility too precisely in its very much criticized 'devoiding power'. This possibility starts to emerge when the pulverization of the mediatic chain into details opens up a space of community, where the paradigm is disrupted and its residuum made presentable in a trace, the ground for a metaphorical link between we and others where the range of possible substitutions knows no pre-established conditions.

Returning to the recognition which enable the disentanglement of the detail, it is possible to describe it now, in Levinas's terms, as the answer to an interpellation which Derrida reformulates as an ethics of "letting be" (Derrida 2004: 172, 179). "To let be" presupposes what has been described as the opening up of a space of community, the reinstating of the linguistic power as a possibility to not not-be. The point of departure of that interpellation (the Other) is thought by Levinas to be exterior to the totalising discourse it helps to deconstruct. That is why the details which trigger our rejection of the discourse of war are usually not scenes of war (such as images of the wounded, or of dead people); those make violence into a spectacle to which we are accustomed to a high degree (Baudrillard 1995; Weber 1997: 96-105). However, there are other images and words (children, details of everyday life or scenes of joy, faces, words of affection and so on), which entangled as they are in the mediatic chains of the discourse of war lose their ability to make sense, but if they are recognized and disentangled they point to their (that is my and the 
Other's) exteriority to that discourse. In recognition we become vulnerable to the Other, losing the invulnerability that the totality of war discourse granted us, but overcoming our vulnerability to the confusing effects caused by the mediatic chains of war discourse. The disenchantment described by Freud as a consequence of wartime is not denied and reversed against the Other any more, but affirmed as the condition where the Self and the Other may meet. As Agamben puts it, only in a world "in which the citizen has been able to recognize the refugee that he or she is", it will be possible to think at the "political survival of humankind" (Agamben 2000: 26), the opening of a space of community. Only if we recognize ourselves in the ones who may not be, does it become possible to let be, to cultivate the possibility to not not-be. It is at this point that the partiality of details encounters the in-finity (see footnote 5) of the Other and our (and the Other's) finitude (mortality), whose acknowledgment has often been understood as the premise for all possible critique of war and violence (e.g., Freud 1974: 49-60; Weber 1997; Connolly 2002: 164-171; Silverman 2003). ${ }^{17}$

It should now be clear how the semiotic practice of disconnection suggested here may represent a strategy of resistance to the discourse of war as characterized above. From the paradigmatic point of view the details, with their lightness and lack of hierarchy, become a contrast to the unbalanced oppositions of the discourse of war. Like the "parity between everything that exists" obtained through the Lucretian pulverisation of reality, the pulverisation of the mediatic cover into details provokes a similar parity between we and they, questioning apocalyptic chosenness and making "empathy" possible (Ezrahi 2002: 66). From the syntagmatic point of view, disconnection represents the necessary precondition for developing our own discourse, it gives us access to the right to speak. ${ }^{18}$ Recognition is in fact always experienced by me, it is my point of contact with the Other, my metaphor for the Other, my way of being for the Other: "Creatures and things invite us to answer to their appeal in a manner which,

\footnotetext{
17 "This identification with humanity through the experience of difference and finitude may achieve its most influential presence in life, though, if death is taken as a theme of reflection and treated as one of the tests around which life is organized" (Connolly 2002: 167).

18 Agamben writes in this sense about the "event of language" as "free use of the common" (Agamben 2000: 117-118).
} 
although fully responsive to their formal coordinates, is absolutely particular to ourselves" (Silverman 2000: 22). Peace, writes Levinas, is always my peace and it manifests itself as an attitude towards speaking (Levinas 1996: 8, 342).

\section{About semiotics}

In conclusion I would like to sum up how war taken as a symptom helps us to reconsider the method of semiotics. I return therefore to the title of this paper to claim that we should bring about in semiotics' practices a shift from the paradigm of globality (totality) to that of partiality. This shift goes, in my opinion, in the same direction as some of the proposals made by the late Michel Foucault for a new intellectual ethics.

The first meaning of partiality which I suggest is a rather political one. Commitment could be a fundamental premise of our activity as semioticians and commitment means taking a position within the field we are studying. This is why it is more useful to discuss the place of semiotics' practices in the social field than the status of semiotics as a science. What we should renounce is the pretence of imagining ourselves to be positioned somewhere outside that which we are observing, the pretence of objectivity or, better to say, that of objectification, which is the premise of all totalising discourses. Foucault described what he presented as a necessary change in the role of the intellectuals as a shift from the universal (the position of "owner of the truth", maitre) to the local, where intellectuals can see themselves as positioned and conditioned within their own field, the field of knowledge, truth, consciousness, discourse. This perspectival (partial) point of view represents an indispensable premise for becoming engaged in the struggle against the forms of totalising power characteristic of our own field (Foucault 1977: 20, 109). Theory should therefore not be seen as the translation of a practice, but as a practice itself, not totalising, but local, regional. It is only from this point of departure that it becomes possible to construct transverse links between different theoretical practices and struggles as a premise for a committed interdisciplinarity.

The epistemological meaning of partiality derives immediately from the political one. The decision to look at our mediatic environ- 
ment as a cover rather than as a web solicits from the semiotician an analytic rather than a synthetic approach, an approach able to discover the part in the whole, the particular in the global, the different in the same. The result need not be a straightforwardly deconstructive kind of semiotics. On the contrary, I am trying to answer the Foucault's request for a criticism which would multiply "signs of existence", having as a fundamental means curiosity because "it evokes the care one takes of what exists and what might exist; a sharpened sense of reality, but one that is never immobilized before it [...] a lack of respect for the traditional hierarchies of what is important and fundamental" (Foucault 1997: 325). The segmenting, disconnecting moment of the semiotic practice suggested here can become the premise for another kind of speech, where the parts do not vanish into the whole and the exteriority of the Other is never finally resumed into the totality of the Same. Lucretius's atomism and Levinas's philosophy both have in-finity as their epistemological basis and so should semiotics.

\section{References}

Agamben, Giorgio 1993. The Coming Community. (Hardt, M., trans.) Minneapolis: University of Minnesota Press.

- 1998. Homo sacer. Sovereign Power and Bare Life. (Heller-Roazen, D., trans.) Stanford: Stanford University Press.

- 2000. Means without Ends: Notes on Politics. (Binetti, V.; Cesarino, C., trans.) Minneapolis: University of Minnesota Press.

- 2005. State of Exception. (Attell, K., trans.) Chicago: University of Chicago Press.

Anderson, Myrdene (ed.) 2004. Cultural Shaping of Violence - Victimization, Escalation, Response. West Lafayette: Purdue University Press.

Barthes, Roland 2000. S/Z. (Miller, R., trans.) Oxford: Blackwell Publishers.

Baudrillard, Jean 1995. The Gulf War did Not Take Place. (Patton, P., trans.) Bloomington: Indiana University Press.

- 1988. Selected Writings. (Poster, M., ed.) Stanford: Stanford University Press.

Benjamin, Walter 1968. Illuminations. (Zohn, H., trans.) New York: Shocken Books.

Benveniste, Émile 1974. Problèmes de linguistique générale. Volume 2. Paris: Gallimard.

Butler, Judith 2004. Precarious Life: The Powers of Mourning and Violence. London: Verso. 
Calvino, Italo 1969. T-zero. (Weaver, W., trans.) San Diego: Harcourt Brace Jovanovich.

- 1996. Six Memos for the Next Millenium. (Creagh, R., trans.) London: Vintage.

Connolly, William E. 2002. Identity/difference: Democratic Negotiations of Political Paradox. Minneapolis: University of Minnesota Press.

Debord, Guy 1995. The Society of the Spectacle. (Nicholson-Smith, D., trans.) New York: Zone.

Deely, John 2005. Defining the Semiotic Animal: A Postmodern Definition of "Human Being" to Supersede the Modern Definition as "Res Cogitans". Sofia: Tip-Top Press.

Derrida, Jacques 1997. Of Grammatology. (Spivak, G. C., trans.) Baltimore: Johns Hopkins University Press.

- 2004. Writing and Difference. (Bass, A., trans.) London: Routledge.

Eco, Umberto 1986. Toward a semiological guerrilla warfare. In: Eco, Umberto, Travels in Hyperreality. (Weaver, W., trans.) New York: Harcourt Brace Jovanovich, 135-144.

Ezrahi, Sidra Dekoven 2002. The future of the Holocaust: storytelling, oppression, and identity — see under: "apocalypse". Judaism 51(1): 61-70.

Foucault, Michel 1977. Microfisica del potere. Torino: Giulio Einaudi Editore.

- 1997. Ethics: Subjectivity and Truth: Essential works of Foucault 1954-1984. Vol. 1. (Rabinow, P., ed.) New York: The New Press.

Freud, Sigmund 1974. Zeitgemässes über Krieg und Tod. In: Studienausgabe, Band 9: Fragen der Gesellschaft. Ürsprunge der Religion. Frakfurt am Main: S. Fischer Verlag, 33-60.

Haber, Honi F. 1994. Beyond Postmodern Politics: Lyotard, Rorty, Foucault. New York: Routledge.

Hitchcock, Peter 2000. Globalization and Bakhtin. In: Brandist, Craig; Tihanov, Galin (eds.), Materializing Bakhtin: The Bakhtin Circle and Social Theory. London: Macmillan.

Jameson, Fredrick 1981. The Political Unconscious: Narrative as a Socially Symbolic Act. London: Routledge.

Kristeva, Julia 1982. Powers of Horror: An Essay on Abjection. (Roudiez, L., trans.) New York: Columbia University Press.

Lacan, Jacques 2001. Écrits: A Selection. (Sheridan, A., trans.) London: Routledge.

Levinas, Emmanuel 1996. Totalité et infini: Essai sur l'exteriorité. Paris: Kluwer Academic.

Lloyd, David 1997. Nationalism against the state. In: Lowe, Lisa; Lloyd, David (eds.) The Politics of Culture in the Shadow of Capital. Durham: Duke University Press, 173-197.

Pettman, Ralph 2004. Reason, Culture, Religion: The Metaphysics of World Politics. New York: Palgrave Macmillan.

Saussure, Ferdinand de 1966. Course in General Linguistics. (Baskin, W., trans.) New York: McGraw-Hill.

Schmitt, Carl 1987. The legal world revolution. Telos 72: 73-89. 
Sebeok, Thomas A. 2001. Global Semiotics. Bloomington: Indiana University Press.

Silverman, Kaja 1983. The Subject of Semiotics. Oxford: Oxford University Press.

- 2000. World Spectators. Stanford: Stanford University Press.

- 2003. All things shining. In: Eng, David L.; Kazanjian, David (eds.), Loss: The Politics of Mourning. Berkeley: University of California Press, 323-342.

Tarasti, Eero 2005. Semiotics of resistance: Being, memory, history - the counter-current of signs (lecture at the Summer School of Semiotics and Structural Studies in Imatra, Finland).

Weber, Samuel 1997. Wartime. In: Vries, Hent de; Weber, Samuel (eds.), Violence, Identity and Self-determination. Stanford: Stanford University Press, 80-105.

Whitebrook, Maureen 2001. Identity, Narrative and Politics. London: Routledge.

\section{От глобальности к парциальности: семиотические стратегии сопротивления дискурсу войны}

Дискурс войны можно рассматривать как симптоматический по отношению к основным дискурсам тотальности (напр. глобализации). Стремясь к упрощению, такие дискурсы принимают вид исчерпывающей парадигмы, но в ходе этого они всегда создают нерепрезентируемый и подлежащий уничтожению остаток. Семиотика может развивать практики сопротивления дискурсу войны, оперируя его синтагматическими цепочками, образуемыми их медиаторами. Такие практики сопротивления основываются на постмодернистской критике тотализирующих дискурсов. Если мелкие детали теряют в синтагматических цепочках дискурса войны свою ценность, то их различение и выделение может открыть “пространство общности”, в котором остаток дискурса войны стал бы репрезентируемым с помощью метафорических замещений. Семиотические практики сопротивления дискурсу войны предполагают теоретический сдвиг от парадигмы глобальности к парадигме парциальности. Парциальность следует рассмаривать как с политической, так и с эпистемологической точки зрения, тем самым она может явиться существенной предпосылкой разработки “семиоэтики”. 


\section{Globaalsuselt partsiaalsusele: Semiootilised vastupanupraktikad sõja diskursusele}

Sõja diskursust võib käsitleda kui totaalsuse diskursuste — nt globaliseerumise - sümptomaatilist väljundit. Lihtsustava seletamise eesmärkidel võtavad sellised diskursused ammendava paradigma kuju, aga seda tehes loovad need alati ka esitamatut ja hävitamisele määratud jääki. Semiootika võib arendada vastupanupraktikaid sõjadiskursusele, pöörates tähelepanu selle süntagmaatilistele ahelatele meedias. Sellised vastupanupraktikad põhinevad totaliseerivate diskursuste postmodernistlikul kriitikal. Kui väikesed detailid kaotavad sõja diskursuse süntagmaatilistes ahelates oma väärtuse, siis nende eristamine ning esile tõstmine võiks avada "ühisruumi", milles sõja diskursuse jääk muutuks esitatavaks metafoorsete asendamiste abil. Semiootilised vastupanupraktikad sõja diskursusele eeldavad teoreetilist nihet globaalsuse paradigmalt partsiaalsuse paradigmale. Seda nihet tuleb mõista nii poliitiliselt — partsiaalsus kui enese positsioneerimine, kui ka epistemoloogiliselt — partsiaalsus põhineb paljususel ja erinevusel. Poliitiline ja epistemoloogiline partsiaalsus on oluliseks eelduseks "semioeetika" väljatöötamisel. 